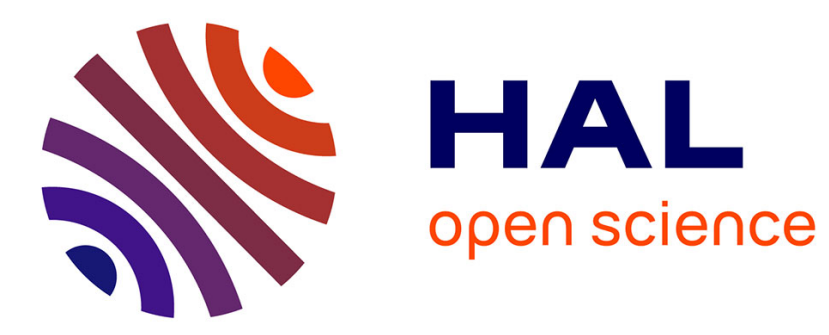

\title{
Internal architecture and evolution of bioclastic beach ridges in a megatidal chenier plain: Field data and wave flume experiment
}

Pierre Weill, Dominique Mouazé, Bernadette Tessier

\section{- To cite this version:}

Pierre Weill, Dominique Mouazé, Bernadette Tessier. Internal architecture and evolution of bioclastic beach ridges in a megatidal chenier plain: Field data and wave flume experiment. Sedimentology, 2013, 60 (5), pp.1213-1230. 10.1111/sed.12027 . hal-00844214

HAL Id: hal-00844214

https://hal-mines-paristech.archives-ouvertes.fr/hal-00844214

Submitted on 28 Nov 2017

HAL is a multi-disciplinary open access archive for the deposit and dissemination of scientific research documents, whether they are published or not. The documents may come from teaching and research institutions in France or abroad, or from public or private research centers.
L'archive ouverte pluridisciplinaire HAL, est destinée au dépôt et à la diffusion de documents scientifiques de niveau recherche, publiés ou non, émanant des établissements d'enseignement et de recherche français ou étrangers, des laboratoires publics ou privés. 


\title{
Internal architecture and evolution of bioclastic beach ridges in a megatidal chenier plain: Field data and wave flume experiment
}

\author{
PIERRE WEILL*, DOMINIQUE MOUAZÉ $\dagger$ and BERNADETTE TESSIER $\dagger$ \\ * MINES ParisTech, Centre de Géosciences, 35 rue Saint-Honoré, 77305, Fontainebleau Cedex, France \\ (E-mail: pierre.weill@mines-paristech.fr) \\ $\dagger$ Morphodynamique Continentale et Côtière, Univ. Caen Basse-Normandie, UMR CNRS 6143, 24 rue \\ des Tilleuls, 14000, Caen, France
}

\begin{abstract}
Beach ridges in macrotidal environments experience strong multi-annual to multi-decennial fluctuations of tidal inundation. The duration of tide flooding directly controls the duration of sediment reworking by waves, and thus the ridge dynamics. Flume modelling was used to investigate the impact of low-frequency tidal cycles on beach ridge evolution and internal architecture. The experiment was performed using natural bioclastic sediment, constant wave parameters and low-frequency variations of the mean water level. The morphological response of the beach ridge to water level fluctuations and the preservation of sedimentary structures were monitored by using side-view and plan-view photographs. Results were compared with the internal architecture of modern bioclastic beach ridges in a macrotidal chenier plain (Mont St. Michel Bay, France) surveyed with ground-penetrating radar. The experimentally obtained morphologies and internal structures matched those observed in the field, and the three ridge development stages identified in ground-penetrating radar profiles (early transgressive, late transgressive and progradational) were modelled successfully. Flume experiments indicate that flat bioclastic shapes play a key role in sediment sorting in the breaker zone, and in sediment layering in the beach and washover fans. Water level controls washover geometry, beach ridge evolution and internal structure. Low water levels allow beach ridge stabilization and sediment accumulation lower on tidal flats. During subsequent water level rise, accumulated sediment becomes available for deposition of new washover units and for bayward extension of the beach ridges. In the field, low-frequency water level fluctuations are related to the $4 \cdot 4$ year and $18 \cdot 6$ year tidal cycles. Experimental results suggest that these cycles may represent the underlying factor in the evolution of the macrotidal chenier coast at the multi-decadal to centennial time scale.
\end{abstract}

Keywords Beach ridge, chenier plain, ground-penetrating radar, macrotidal flat, tide fluctuations, washover, wave flume modelling.

\section{INTRODUCTION}

Cheniers are stabilized wave-built ridges that have been isolated from the shore by a band of prograded mudflat (Otvos \& Price, 1979; Otvos, 2005). In subsequent depositional phases, chenier plains receive muddy sediment during mudflat progradation, and coarse-grained, wave-reworked sediment during beach ridge construction.

Two types of chenier can be distinguished. The first type develops along open ocean coasts near the outflow of large rivers that provide the 
sediment material for mudflat progradation and beach ridge construction (e.g. Anthony, 1989; Augustinus et al., 1989; Qinshang et al., 1989; McBride et al., 2007). The second type occurs in mesotidal to macrotidal bays and estuaries (Greensmith \& Tucker, 1969; Woodroffe et al., 1983; Chappell \& Grindrod, 1984; Lee et al., 1994; Vilas et al., 1999; Neal et al., 2002; Hayward, 2007; Rodríguez-Ramírez \& YáñezCamacho, 2008). Muddy sediment is from fluvial or tidal sources, and the coarse-grained material essentially comes from the biological production on the tidal flats. Several discussions of the topic provide good synthetic summaries (Augustinus, 1989; Short, 1989; Shuisky, 1989; Xitao, 1989; Otvos, 2005; Holland \& Elmore, 2008). Cheniers and chenier plains have been used in stratigraphic studies to reconstruct Holocene sea-level curves (Short, 1988; Wang \& Van Strydonck, 1997; Saito et al., 2000; Ruiz et al., 2005) and delta development sequences (Penland \& Suter, 1989; Draut et al., 2005; McBride et al., 2007).

Delta-associated chenier plain deposition is generally controlled by distributary avulsion cycles, as in the archetypal example of the Louisiana chenier plain (Draut et al., 2005). In sheltered bay or estuary environments, several depositional models have been proposed to explain the episodic development of cheniers; these include storm impact (Lee et al., 1994), climate changes including rainfall variations (Rhodes, 1982), small transgressive pulses and high energy events that provide coarse sediment material (Rodríguez-Ramírez \& Yáñez-Camacho, 2008). However, despite the fact that these cheniers occur in mesotidal to macrotidal settings, none of the above models investigated the role of tides in their dynamics and construction.

Descriptions of chenier internal architecture are relatively limited, based on cores and trenches, as well as natural field exposures (Byrne et al., 1959; Greensmith \& Tucker, 1969; Hoyt, 1969; Augustinus, 1980; Rhodes, 1982; Cangzi \& Walker, 1989; Penland \& Suter, 1989; Xitao, 1989; Lee et al., 1994; Pontee et al., 1998; Vilas et al., 1999). Neal et al. (2002) used ground-penetrating radar (GPR) data to provide detailed information on the internal architecture of bay-head cheniers. On the basis of GPR studies, supplemented by detailed sediment analysis, Weill et al. (2012) provided information about the internal architecture of modern beach ridges in a megatidal chenier plain. The study was carried out in
Mt. St. Michel Bay (north-west France) and combined high-frequency GPR profiles and Xray tomography of sediment cores to describe sedimentary structures, lithofacies and geotechnical characteristics of modern beach ridges.

The internal architecture of the chenier ridges in Mt. St. Michel Bay suggests that beach ridge evolution there is driven by fair weather and storm wave activity during high spring tide (HST) flooding. On a multi-annual time scale, the frequency of high spring time flooding shows a strong variability, with a periodicity related to the 4.4 year and 18.6 year tidal cycles. Related flume experiments provided a means to study bioclastic sediment transport at the level of individual particles (Weill et al., 2010) and helped in understanding the internal sedimentary structures of the beach ridges (Weill et al., 2012).

In this article, a flume experiment is reported that was designed to investigate one specific factor in chenier formation: the role of lowfrequency tidal fluctuations. The decoupling of other forcing parameters made it possible to test the premise that these fluctuations alone are mainly responsible for the internal architecture of the investigated beach ridges. The experimental design utilizes a changing water level in the flume in conjunction with constant wave forcing. Sediment sorting, transport and deposition processes are defined in the various beach ridge zones that include the breaker zone, the foreshore and backslope. Experimental results are compared with relevant field observations, and the impact of low frequency tide level fluctuation on beach ridge morphology and internal structure is discussed.

\section{CHENIER PLAIN AND MODERN BEACH RIDGES IN MONT ST. MICHEL BAY}

To fully appreciate the relevance of the flume experiment and understand their importance, it is necessary to provide a short description of the geological and hydrodynamic conditions of the Mt. St. Michel Bay area and of the sedimentary architecture of beach ridges as identified by GPR surveys (Weill et al., 2012).

\section{Geological settings}

Mont St. Michel Bay (north-west France) is located between the Cotentin and the Brittany peninsulas (Fig. 1). The large tidal range, reaching $14 \mathrm{~m}$ during HST, has resulted in an 


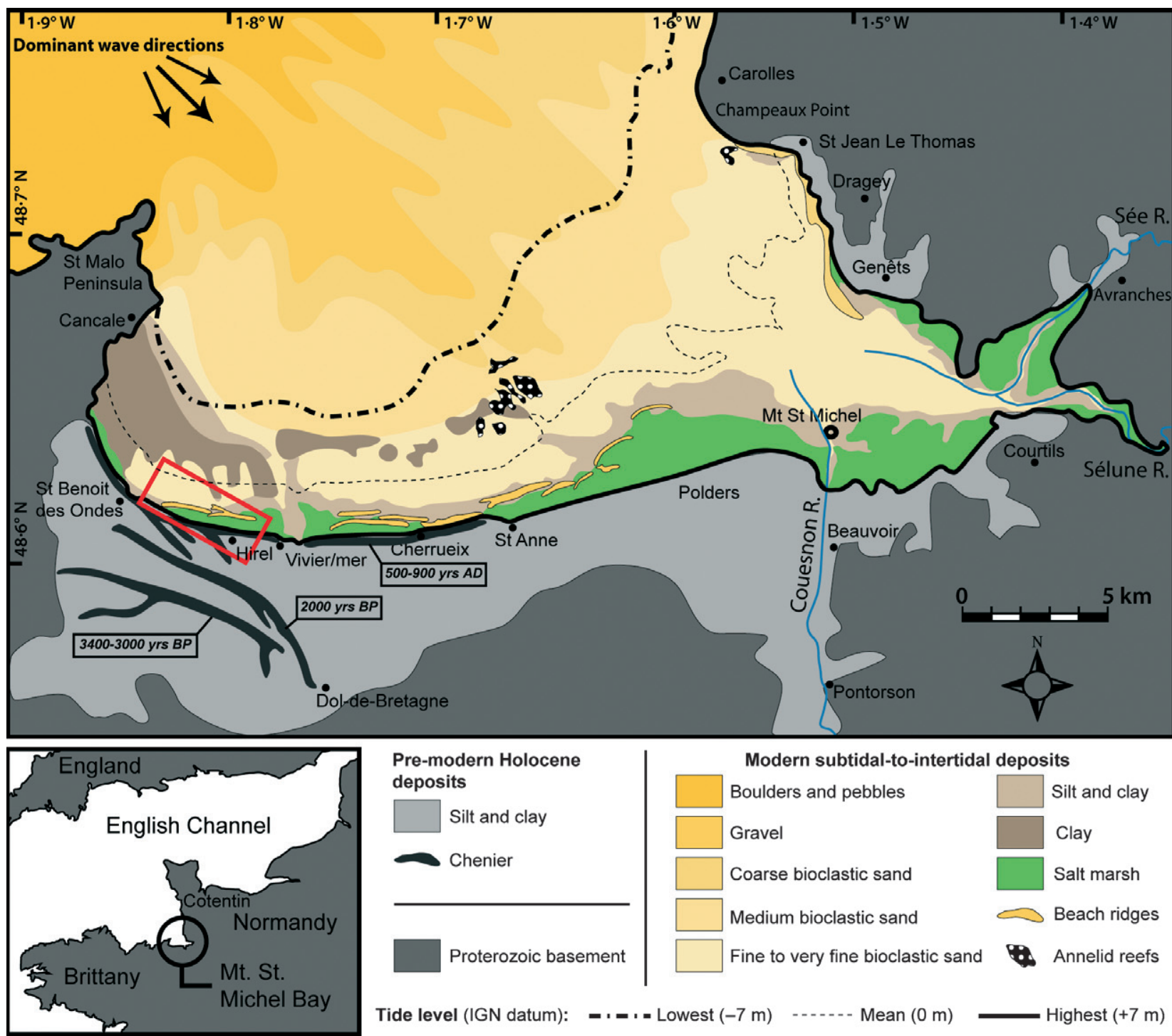

Fig. 1. Geological map and surface sediment distribution in Mt. St. Michel Bay. Red frame: site of beach ridges studied by GPR method. Radiocarbon ages of chenier ridges from Morzadec-Kerfourn \& Meury (1995). This figure was based, in part, on Tessier et al. (2006).

intertidal area of $250 \mathrm{~km}^{2}$ (Larsonneur, 1994). The wide embayment in the south-west is occupied by extensive tidal flats, on the upper part of which are found a series of bioclastic beach ridges, along the salt marsh edge (Fig. 2). Extensive coring in the pre-modern Holocene deposits revealed sets of shore-parallel shell ridges anchored between prograding silt-dominated to mud-dominated units (L'Homer et al., 2002). Following Otvos \& Price (1979), the relict ridges are defined as cheniers; and the area they occupy with the intervening mudflats is defined as a chenier plain. The modern beach ridges are composed of coarse to very coarse bioclastic sand, and of fine siliclastic sand reworked from the tidal flat (Weill et al., 2010).

\section{Hydrodynamic setting}

The formation, morphology and onshore migration of the beach ridges are related to wave processes. The western embayment accommodates a low wave regime. The prevailing swells that enter the bay from the north-west are dissipated across the wide and shallow tidal flat and lose between one half and two thirds of their amplitude by the time they reach the high tide line. Measurements of residual storm wave characteristics using a pressure sensor on the upper tidal flat during HST revealed a significant wave height of about $0.3 \mathrm{~m}$, a maximum height of about $0 \cdot 5 \mathrm{~m}$, with a peak period of $12 \mathrm{~s}$. 


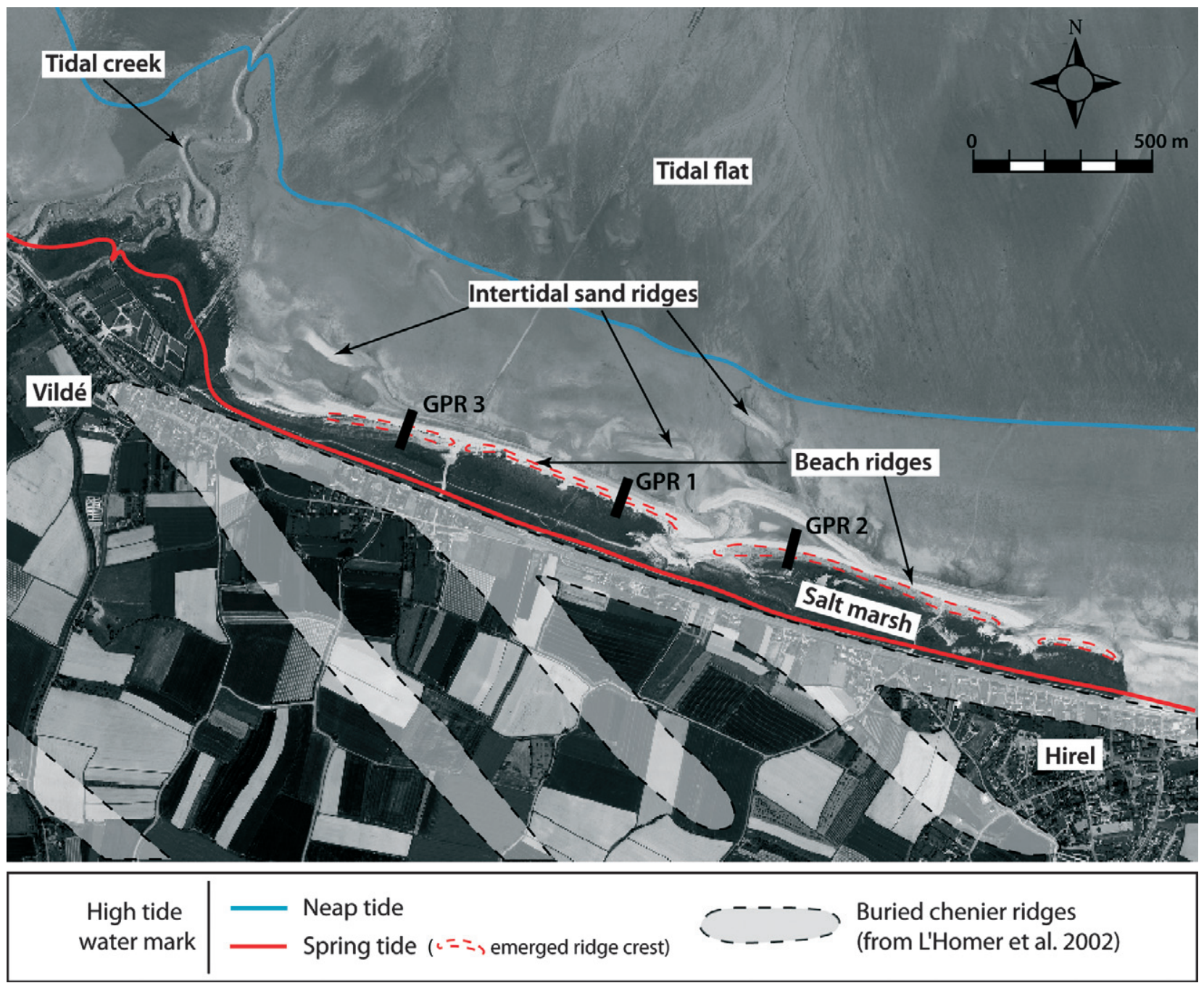

Fig. 2. Aerial orthorectified photograph of the study site in 2006, showing the investigated beach ridges and the upper tidal flat. Black blocks: GPR profile sites (Weill et al., 2012). Buried chenier ridges identified in L'Homer et al. (2002) are shown with shaded grey and dashed lines. The high tide water level oscillates between the blue line (neap tides) and the red line (spring tides). High spring tides completely cover the salt marsh and the beach ridges are overtopped by waves.

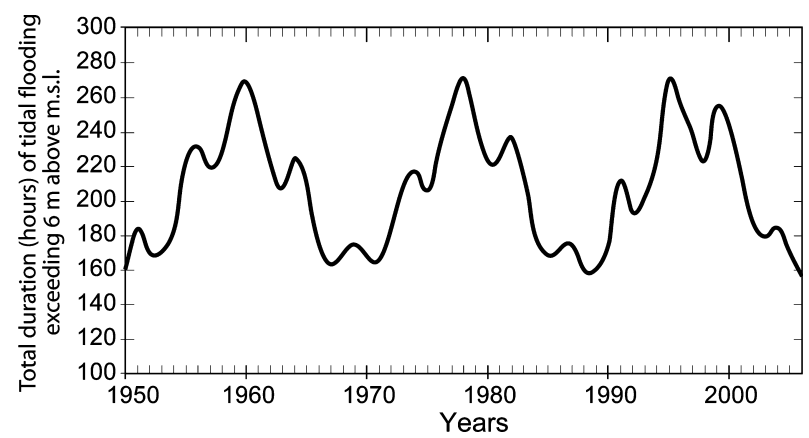

Fig. 3. Total annual duration (in hours) of tidal flooding exceeding $6 \mathrm{~m}$ above mean sea-level (m.s.l.) between 1950 and 2006. The curve displays fluctuations associated with the 4.4 year and 18.6 year tidal cycles.
The duration of wave activity within a part of the tidal flat profile is modulated by tides. Only the highest spring tides may reach the upper tidal flat (Bonnot-Courtois et al., 2004). This fact influences the onshore migration of modern beach ridges. The lower the elevation of ridges on the tidal flat, the more frequently they are submerged and reworked by waves. Consequently, while intertidal sand ridges move landward at the speed of 10 to $50 \mathrm{~m} \mathrm{year}^{-1}$, the marsh edge ridges shift only at 1 to $2 \mathrm{~m} \mathrm{year}^{-1}$ in the same direction (Bonnot-Courtois et al., 2004). Intertidal ridges supply significant volumes of sediment to beach ridges located on the upper tidal flat. 
Fig. 4. Three stages of beach ridge evolution identified in the GPR survey. (A) Early transgressive stage ('GPR 1' profile, Fig. 2). (B) Late transgressive stage ('GPR 2' profile, Fig. 2). (C) Progradational stage ('GPR 3' profile, Fig. 2). HSTL - high spring tide level (after Weill et al., 2012).
A

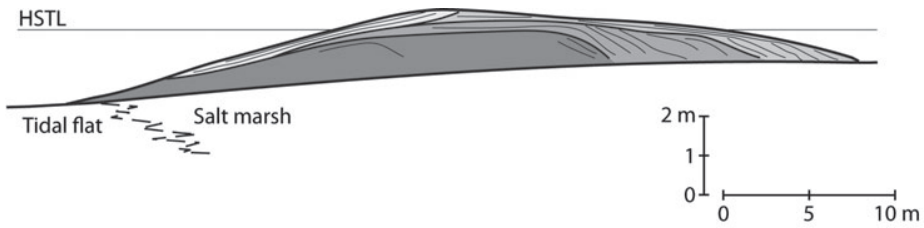

B
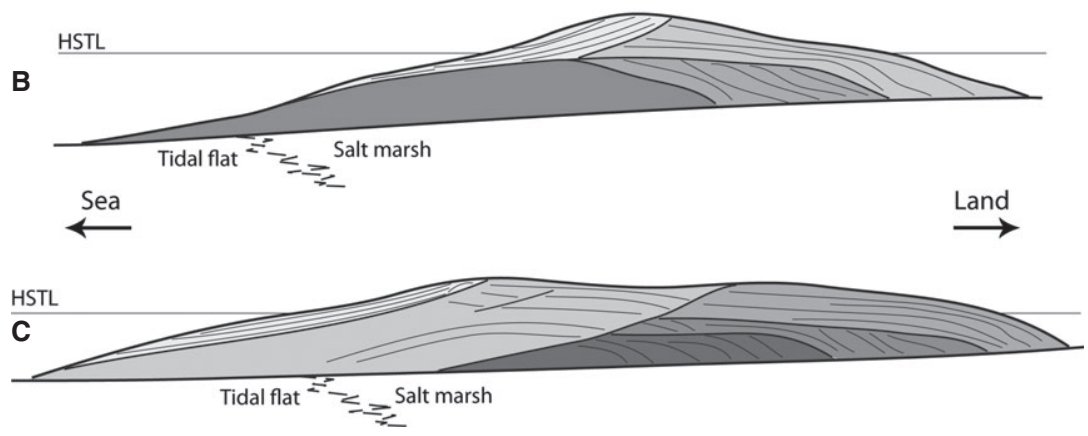

The total duration of tidal flooding that exceeded $6 \mathrm{~m}$ above m.s.l. (mean sea-level) has been determined for each year between 1950 and 2006 (Fig. 3). Tide tables of the National Oceanographic Service (SHOM) were utilized in the calculations. Above this elevation, overwash events on the beach ridges become significant. The flooding time curve displays periodicities of 4.4 years and 18.6 years. Durations of HST inundation and beach ridge reworking vary between $160 \mathrm{~h}$ per year during the troughs of the tidal cycles, and $280 \mathrm{~h}$ per year during the highest peaks (Fig. 3).

\section{Internal architecture of modern beach ridges}

The internal structure of beach ridges has been investigated using $900 \mathrm{MHz}$ GPR antenna (Weill et al., 2012). Three cross-shore profiles (Fig. 2) summarize their evolution, from early and late transgressive to progradational stages (Fig. 4).

1 Early transgressive beach ridges (Fig. 4A, 'GPR 1' in Fig. 2) are low-crested ( $<2 \mathrm{~m}$ thick) and totally submerged during HST. Washover sedimentation was subaqueous and resulted in high-angle landward dipping foreset stratification. The bayward slope was essentially erosional. These ridges experienced both landward extension and migration over the upper tidal flat and salt marsh.

2 Late transgressive beach ridges (Fig. 4B, 'GPR 2' in Fig. 2) were thicker (up to $3 \mathrm{~m}$ ) and their crests were above the HST water level. Overwash deposits featured two distinct sedimentation patterns (Schwartz, 1982). The lower part of the lobe, deposited in the flooded salt marsh, consisted of landward-dipping foreset laminae. The upper part was produced by sub-aerial sedimentation and displayed sub-parallel, low angle landward dipping strata. These ridges no longer experienced landward migration. The height of vertical accretion on the landward slope was limited by the highest water level for wave overtopping, when HST tides coincided with a storm surge.

3 Progradational beach ridges (Fig. 4C, 'GPR 3' in Fig. 2) were composed of amalgamated individual ridges. This configuration occurred when late transgressive ridge thickness prevented overwash. Landward migrating intertidal sand ridges could not be reworked and incorporated in the beach ridge by washover. Instead, they healed the scar of the eroded beach face of late transgressive ridges, resulting in a bayward extension of the latter (Fig. 4C).

In summary, the analysis of GPR profiles suggested that the internal architecture and the evolution of the beach ridges were closely related to the level of HST flooding, which controlled access to overwash and the deposition of washover lobes. Moreover, time series have shown that there were significant variations of the level and duration of extreme tidal flooding on a multi-decadal time scale (Fig. 3). The following question then arises: Can the low frequency for tidal level fluctuations alone be responsible for the evolution and internal architecture of modern beach ridges in a megatidal chenier plain environment? In addressing this issue, a wave flume experiment has been conducted with constant wave forcing and a fluctuating water level. 
A
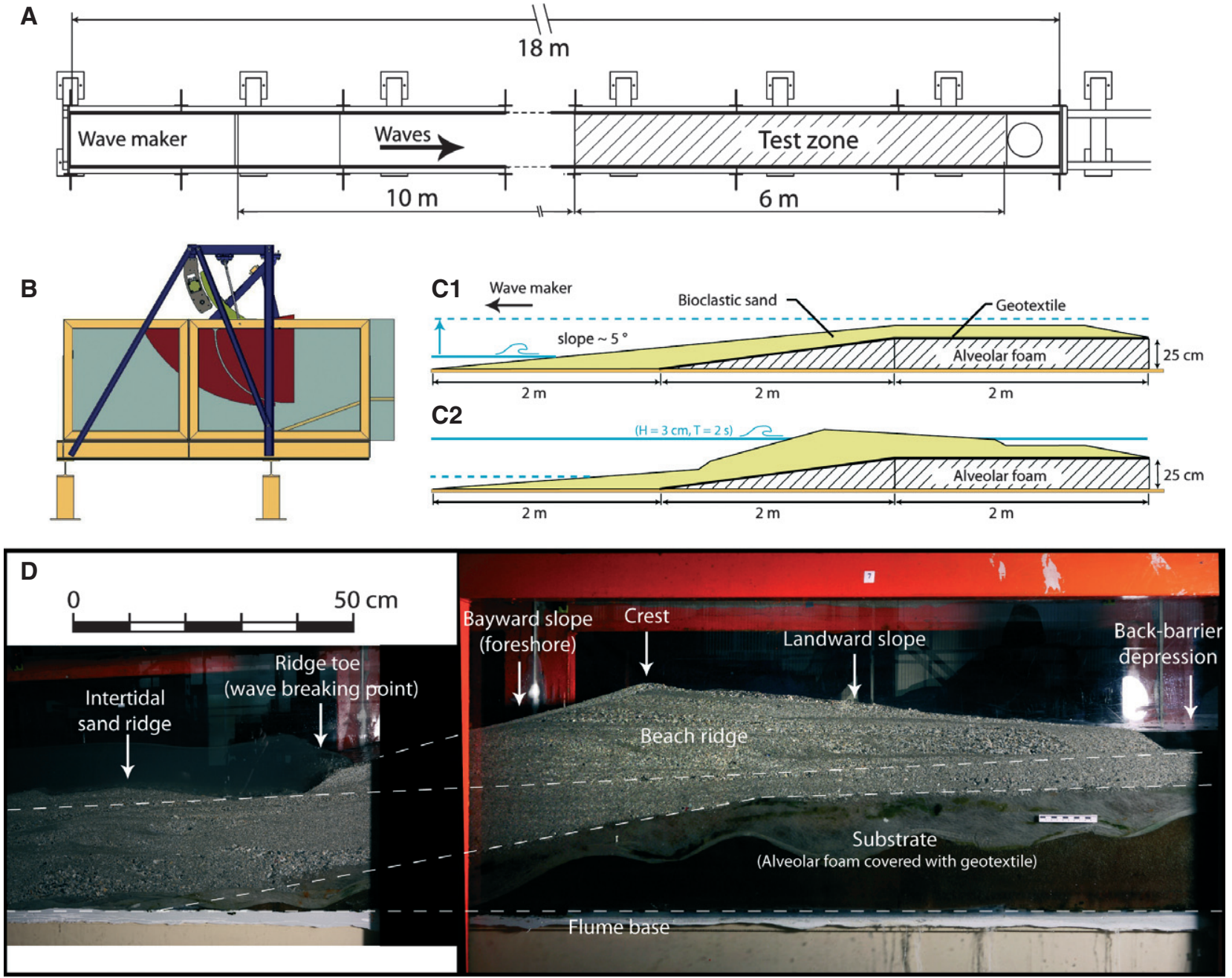

Fig. 5. Experimental set-up. (A) Plan view of the wave flume, showing the position of the test zone. (B) Side view of the piston-type wave maker. (C) Scheme of the test zone showing the initial repartition of the sediment before the experiments (C1) and the equilibrium shape after wave action and raised water level (C2). (D) Side view of the test zone showing the beach ridge at equilibrium.

\section{FLUME EXPERIMENT}

The methodology adopted in this experimental study links the processes of sediment transport to the preservation of sedimentary structures at the scale of a sedimentary body. It is a middle ground between: (i) real-scale models, which investigate the processes of sediment transport and associated bedforms (e.g. Shields, 1936; Bagnold, 1956); and (ii) stratigraphic models used to test the sensitivity of the external forcing parameters during the development of largescale sedimentary systems and the creation of the stratigraphic record (Paola, 2000; Muto, 2001; Muto \& Steel, 2001, 2004; Hickson et al., 2005; Martin et al., 2009; Paola et al., 2009).

Experimental modelling at the scale of sedimentary bodies in coastal environments is relatively limited, and is mostly focused on beach morphodynamics. In addition to surf and swash zone hydrodynamics, experiments have examined the equilibrium of beach profiles (Wang \& Kraus, 2005; Lopez de San RomanBlanco et al., 2006; Michallet et al., 2007; Grasso et al., 2009a), the dynamics of surf bars (Grasso et al., 2009b), the erosion of the beach face (van Thiel et al., 2008) and beach nourishment (Dette et al., 2002). There has not been any previous experimental investigation of the link between the hydrodynamic processes and the construction and preservation of the fine-scale sedimentary architecture in beach ridges. In particular, the experiment reported here was designed to investigate the role of low frequency tide level fluctuations in the dynamics and sedimentary structures of beach ridges. 


\section{Experimental setup}

The experiment was performed in an $18 \mathrm{~m}$ long, $50 \mathrm{~cm}$ wide and $65 \mathrm{~cm}$ high glass-sided wave flume (Fig. 5A). Waves were generated using a piston-like vertical wave maker (Fig. 5B). Strain sensors allow a continuous analysis of reflected waves and absorption. The water level in the flume was recorded using a series of resistive probes with an acquisition frequency of $32 \mathrm{~Hz}$.

Wave parameters were scaled using a Froude similitude. Waves were measured in the field at the foot of a modern beach ridge using a pressure sensor. This residual swell was associated with the passing of a cold winter front off the coast of Brittany. Significant wave heights ranged between $30 \mathrm{~cm}$ and $40 \mathrm{~cm}$, peak periods between $4 \mathrm{sec}$ and $12 \mathrm{sec}$. With a scale ratio of 1 to 10 , this provides wave amplitude in the flume between $3 \mathrm{~cm}$ and $4 \mathrm{~cm}$, with periods of $3.75 \mathrm{sec}$ and 1.25 sec. In order to simplify the forcing parameters in the experiment and because of the size limitation of the wave flume, monochromatic waves with a period of 2 sec were generated.

The objective of the experiment was not to create a perfectly scaled beach ridge in a flume, but to observe the processes of sediment sorting and transport in the breaker and swash zone, and to create deposits associated with washovers. The complexity of the sediment composing the investigated beach ridges, in terms of shape and heterogeneity, plays an important role in understanding the dynamics of these sedimentary bodies, and to explain the bedding observed (Weill et al., 2010). It would be nearly impossible to scale down the sediment and maintain its characteristics at the same time. For

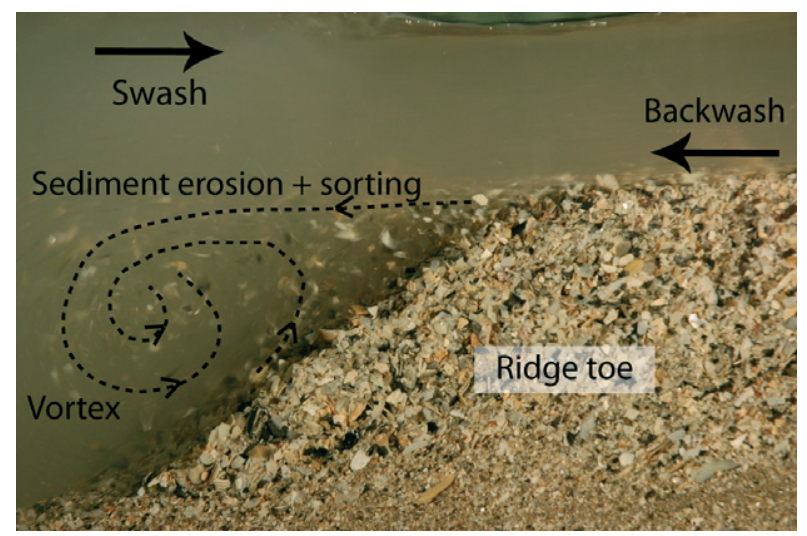

Fig. 6. Sediment erosion and sorting in the breaker zone. The convergence of the swash and the backwash creates a strongly erosive vortex that forms a topographic step at the ridge toe. this reason, the scaling of the grain size did not follow a rigorous dynamic similitude. Sediment obtained from the natural beach ridges has been directly utilized in the flume, after removing grains coarser than $5 \mathrm{~mm}$. The relevant criterion here is the capacity of the generated waves to erode and transport sediment. Previous work on threshold of motion for this same sediment under unidirectional current (Weill et al., 2010) quantified critical shear stress between $1 \cdot 10^{-2}$ and $4 \cdot 10^{-2} \mathrm{~N} \mathrm{~m}^{-2}$ with mean velocity between 0.1 and $0.5 \mathrm{~m} \mathrm{~s}^{-1}$. These low values are easily reached in the breaker and swash zone, where turbulence is high and where rapid velocity inversions further increase the shear stress on the bed.

Sediment taken from the field was placed in the flume over a foam substrate covered with geotextile. The inclination of the foam substrate was $7^{\circ}$ over a distance of $2 \mathrm{~m}$. It was fronted by a $2 \mathrm{~m}$ wide flat surface that reached a height of $25 \mathrm{~cm}$ (Fig. 5C). The introduced sediment formed a $4 \mathrm{~m}$ wide beach with a slope of $5^{\circ}$ (Fig. 5C1).

A preconditioning phase was used to settle the sediment prior to starting the experiment. It consisted of slowly filling the flume up to a water depth of $33 \mathrm{~cm}$, with constant wave forcing. The beach rapidly adjusted its profile to the wave conditions, with a mean slope of $c a 15^{\circ}$ (Fig. 5C2). Overwash flows created a backslope with an angle of $c a 5^{\circ}$. The associated hydrodynamic and sedimentary processes will be described in the Experimental results section. The equilibrium beach ridge morphology obtained was the starting point of the experiment (Fig. 6).

To investigate the role of low-frequency water level fluctuations in the morphological evolution of the experimental beach ridge, several cycles of increasing and decreasing water depth were simulated, with constant wave parameters. This process involved empting and filling the flume with fresh water. The water level fluctuated between three positions (Fig. 9): (i) the initial $33 \mathrm{~cm}$ water depth resulted in the reworking of the beach face; (ii) a low water level at $0.27 \mathrm{~m}$ depth acted on the lower shoreface and sediment surface off the ridge; and (iii) a high water level at $0.37 \mathrm{~cm}$ depth triggered major overwash. To ensure equilibrium conditions, the water depth was kept constant in the flume for the duration of ca 90 min between each rising and falling water stage. The morphological response of the beach ridge and the preservation of sedimentary structures were monitored by using side-view and plan-view photographs. 

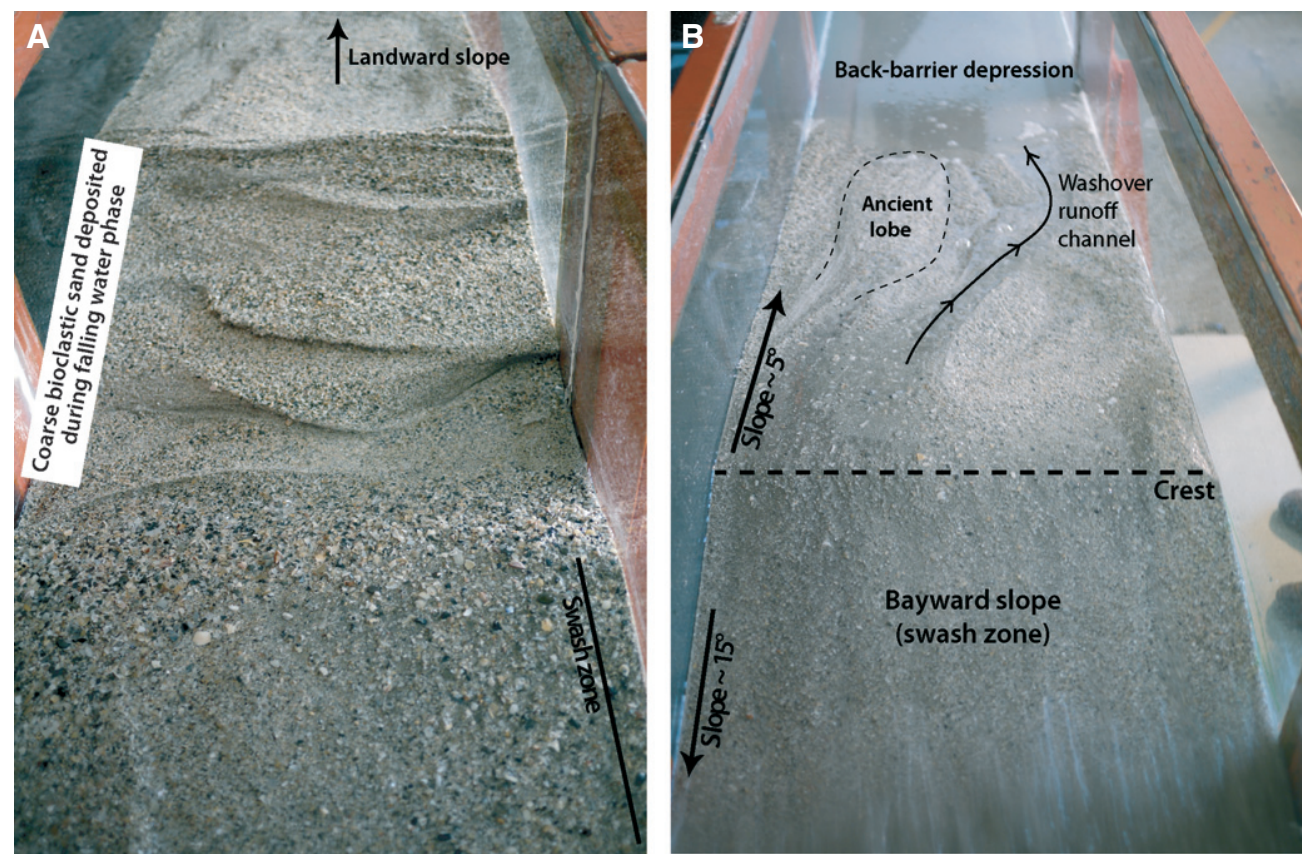

Fig. 7. Evolution of the beach ridge surface with changing water level. (A) Falling water level: Coarse sediment removed from the breaker zone is deposited after swash ends and gradually covers the foreshore during falling water stage. (B) Rising water level: The coarse sediment previously accumulated on the foreshore is transported on the landward slope. Waves breach and erode the beach ridge crest.

\section{EXPERIMENTAL RESULTS}

The bayward slope of the initial ridge rapidly reached an equilibrium beach profile under wave action, with a mean slope of $c a 15^{\circ}$ (Fig. 5D). This steep foreshore was associated with a surging wave breaker type. Consequently, there was no surf zone. The wave breaking point corresponded to the lower limit of the swash zone. The run-up length was $c a 60 \mathrm{~cm}$. The interaction between the swash and the backwash created a strongly erosive vortex at the breaking point, which shaped a topographic step at the toe of the ridge (Fig. 5D). The suspended sediment was sorted by centrifugal forces. Coarse bioclastic particles appeared to be preferentially eroded and transported in the swash zone because of the large lifting surface of the particles compared with their weight (small apparent settling velocity). The fine siliclastic sand remained mostly in suspension in the breaker zone. The bayward slope of the ridge displayed an upward-coarsening grain-size trend. Fine sediments formed the ridge toe, while coarser bioclasts occurred at the upper swash limit.

When a falling water level was imposed, to simulate tidal fluctuations, the breaker and swash zones shifted downslope over the foreshore. Coarse bioclastic sediment left behind the migrat- ing breaker zone gradually covered the foreshore between high and low water level (Fig. 7A). When the water level in the flume was very low, the flat offshore surface was reworked by waves. The onshore asymmetry of the waves formed ripples and small bars; these migrated towards the ridge, and provided the ridge with more sediment. When water levels were increased, the breaker zone shifted upslope over the foreshore and removed sediment. This eroded sediment was sorted in the breaker zone. The foreshore aggraded as 1 to $2 \mathrm{~mm}$ diameter bioclasts accumulated in the swash zone. In addition to the fine siliclastic fraction, coarse bioclastic particles of 4 to $5 \mathrm{~mm}$ diameter were also left behind. These particles were too heavy for further transport. The granulometry of the gently inclined sea floor off the ridge toe was strongly modified when it was overridden by the still rising, landwardadvancing breaker zone.

As water level was rising in the flume, the swash current began to impact the berm crest, composed of coarse bioclasts. The swash current cut a small breach into the berm and was channelized further landward on the ridge backslope. Due to small overwash volume, water rapidly infiltrated the ridge top and the eroded sand formed small washover lobes on the backslope of the ridge above static water level. Channel 


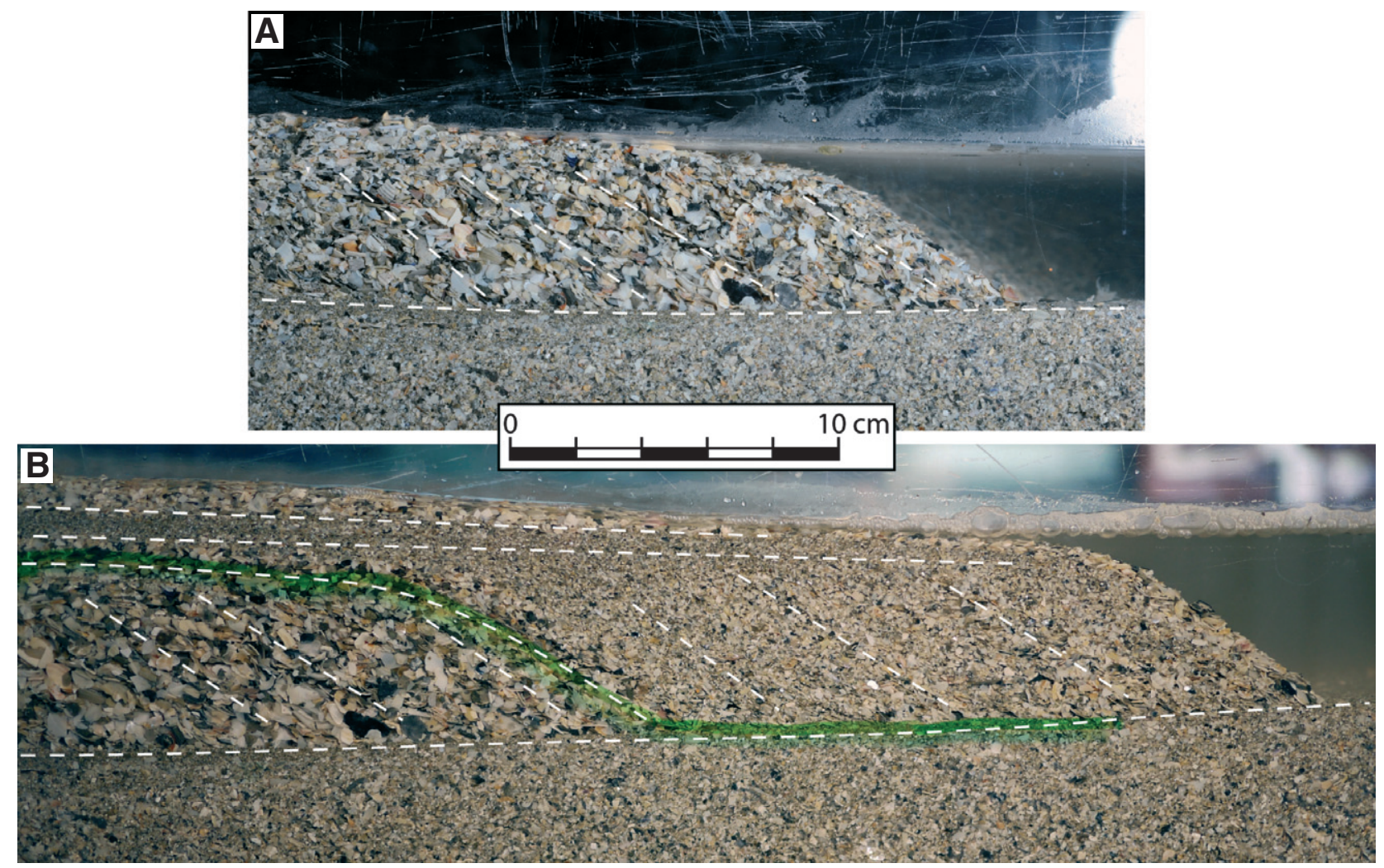

Fig. 8. Formation and evolution of washover fans in flume experiments. (A) The first deposits are the coarsest; they are composed of sediment eroded from the upper beach and ridge crest. Because deposition takes place below static water level, the deposits consist of high-angle landward dipping foreset laminae. (B) When the landward slope is overextended, the overwash fails to transport sediment down to the flooded back-barrier depression. Sand is deposited above the high water level in washover sheets, with typical low angle sub-parallel laminae. Foreset progradation occurred extremely rapidly in the experiment. The two photographs were taken within a few minutes interval.

bifurcation resulted in additional overwash fans at the foot of the ridge backslope (Fig. 7B).

When the breach size widened, the ridge became saturated by increasing overwash. When overwash no longer infiltrated the backslope, it poured into the flooded depression behind the ridge. Entering standing water, the overwash decelerated suddenly. Landward-inclined high angle foreset strata formed (Fig. 8). The oldest deposits were the coarsest (Fig. 8A) because they consisted of coarse bioclastic sand, eroded from the ridge crest and backslope by the early overwash events. Because the ridge crest and backslope sediments were gradually washed out from the coarsest shell debris, the washover deposits became finer (Fig. 8B).

The backslope of the beach ridge was extended landward. The backslope evolved during the progradation of foreset laminae. As the ridge widened and washover could not continue to transport sediment to the flooded low area in its rear, the sediment in the flume was deposited

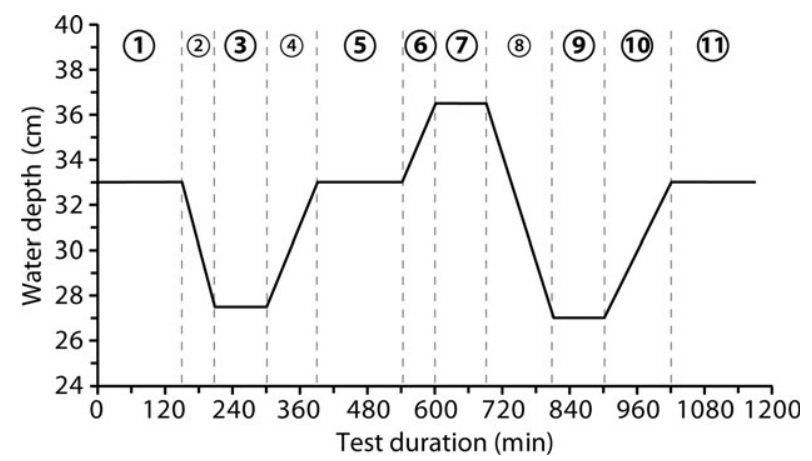

Fig. 9. Mean water level fluctuations in the flume during the experiments. Bold numbers refer to stages described in Table 1 and Fig. 10.

above static level in the form of sheet-like, landward-dipping sub-parallel, low-angle laminae (Fig. 8B). The vertical transition in the washover lobe between high-angle foreset laminae and the sheet-like, gently inclined layers corresponded to the static water level in the flume. 
(1)

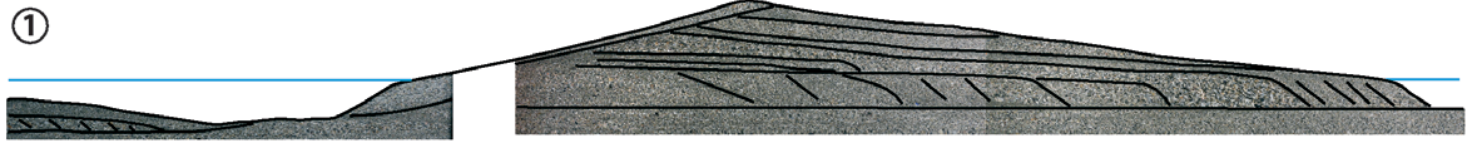

(3)

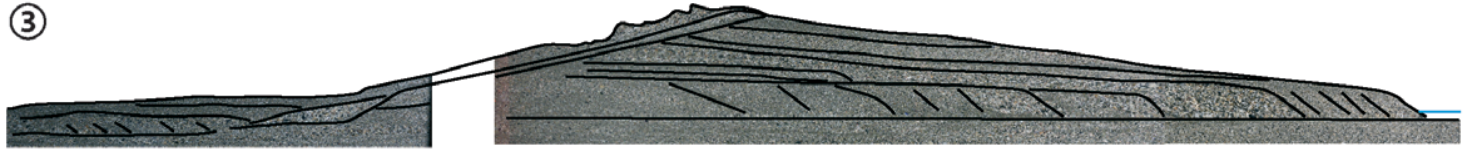

(5)

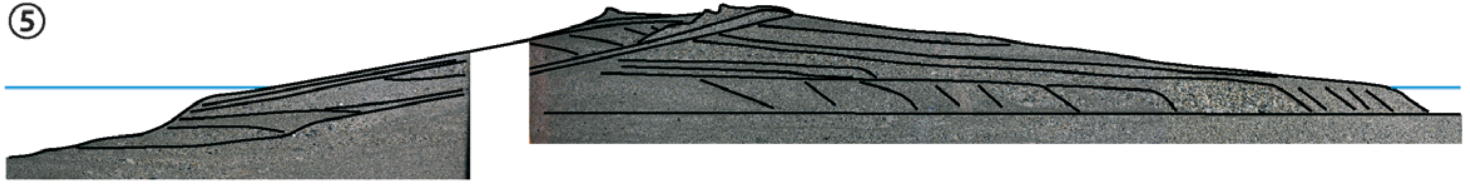

(6)
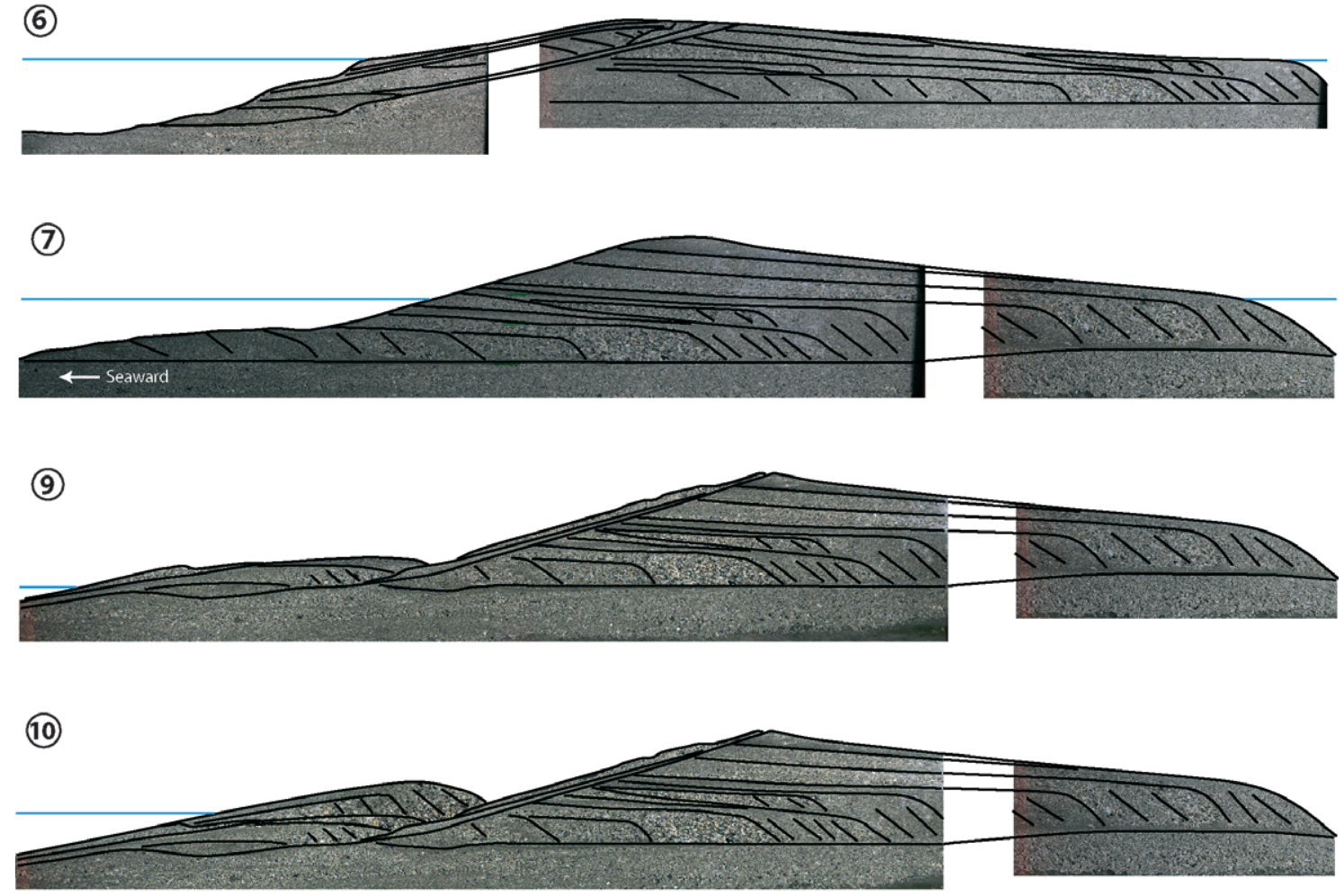

(11)

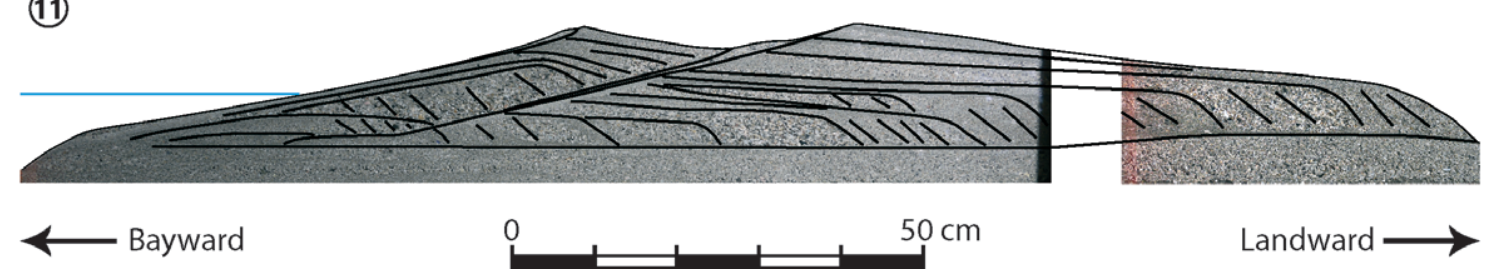

Fig. 10. Evolution of the experimental beach ridge in response to mean water level fluctuations in the flume. Each stage is described in detail in Table 1, and its timing in the experiment is reported in Fig. 9. 
Table 1. Flume tank stages of beach ridge development. The timing of each stage is defined in Fig. 9, and the morphology of the experimental beach ridge is interpreted in Fig. 10.

\section{Stage 1. Initial stage - Rising water level}

The initial ridge morphology is created by wave impact on the foreshore during rising water level. The ridge is composed of washover foresets covered by sub-aerial landward-inclined $\left(c a 5^{\circ}\right)$ washover sheets deposited above water level. The foreshore slope is steeper $\left(c a 15^{\circ}\right)$ and narrower than the landward slope and truncates underlying older washover deposits. The bayward-inclined beach laminae, along with their grain size and thickness increases towards the ridge crest. Driven by asymmetrical waves, the intertidal sand ridge bayward of the toe of the simulated beach ridge migrates landward.

\section{Stage 3. Falling water level}

As water level declines, the breaker zone moves downslope on the modelled foreshore. Coarse bioclasts are sorted and deposited landward of the swash zone. Sand covers the entire foreshore to low water mark. Wave action drives landward migration of the intertidal sand ridge which reaches the beach ridge toe. Wave-reworked sediment is deposited on the bayward beach ridge slope.

\section{Stage 5. Rising water level}

The breaker zone moves up the foreshore. The beach ridge toe migrates landward. Sediment is reworked at the ridge toe. Coarse bioclastic sand is sorted in the breaker zone and transported by swash currents. Foreshore aggradation. Prograding foresets develop at the landward limit of the foreshore. A new ridge crest forms seaward of the former ridge crest. Sediments of the Stage 1 foreshore unit are preserved beneath most recently aggraded foreshore deposits.

\section{Stage 6. Continued water level rise}

The breaker zone continues to shift over the foreshore. A new topographic step forms higher on the foreshore. The highest water level deposits of Stages 1 and 5 are eroded. Erosive breaching of the crest opens the path for overwash. The small volume of overwashed water is rapidly absorbed by the ridge. The ridge crest erodes. Larger overwash volumes reach the back-barrier zone. Very thick sand laminae in the washover foresets are deposited at the highest water level. Sand aggrades at the landward limit of the backshore surface.

\section{Stage 7. Rise to record-high level}

Increased overwash erodes the ridge crest. Intense foreshore erosion takes place. Old washover deposits are exposed in the bayward ridge slope. The ridge migrates landward by $90 \mathrm{~cm}$ in a landward direction in $2.5 \mathrm{~h}$. Sediment eroded from foreshore is deposited in large washover foreset laminae. When the ridge backslope becomes overextended, washover flow is dissipated by infiltration. Deposition of subaerial washover sand sheets. Vertical aggradation of landward ridge face continues until aggrading crest blocks overwash. Washover foreset laminae deposited in Stage 6 are identifiable under the beach ridge crest.

\section{Stage 9. Low water level}

The breaker zone moves downslope. Coarse bioclastic sand is sorted and deposited at the landward limit of the swash zone. It covers the foreshore to the low water level. Grain size decreases in a downslope direction. When the declining water level reaches a given elevation, the sand bayward of the simulated beach ridge is reworked by waves. Waves transport sand landward. Asymmetrical landward-migrating sand ridges stabilize at the ridge toe.

\section{Stage 10. Rising water level}

An intertidal sand ridge shifts landward over the bayward beach ridge slope. Landward-dipping foresets (ca $35^{\circ}$ ) are deposited. Water fills the low zone above the static level between the intertidal sand ridge and the beach ridge. Conditions are favourable to washover foreset deposition. The sand texture displays a coarsening trend from the sand ridge toe towards the washover foresets. A convex face develops in the bayward slope as substantial volumes of sediment remain in transport and the sand ridge migrates landward.

\section{Stage 11. Stable high water level}

Sediment supply decreases towards the beach ridge. Grain size decreases in the same direction. Intertidal bottom off the beach ridge has been eroding during the previous stages. Increased water depth weakens breakers and reduces the transported sediment volumes. Coarser bioclasts have already been removed and incorporated in washover fans. Finer-grained deposits cover the foreshore. The low area between the two ridges is filled by sediment. Subaerial washover deposits display a trend from washover foreset laminae $\left(35^{\circ}\right.$ dip angle) to washover sheets $\left(7^{\circ}\right)$. A steeper angle $\left(11^{\circ}\right)$ characterizes the concave bayward beach ridge slope, now in equilibrium.

The hydrodynamic and sedimentary processes that impacted the ridge foreshore and backslope resulted in internal sedimentary structures and depositional geometries that were strongly influ- enced by water level fluctuations. Table 1 describes in detail the morphological evolution of the ridge and its internal architecture during fluctuating water cycles (Fig. 9). A side view 


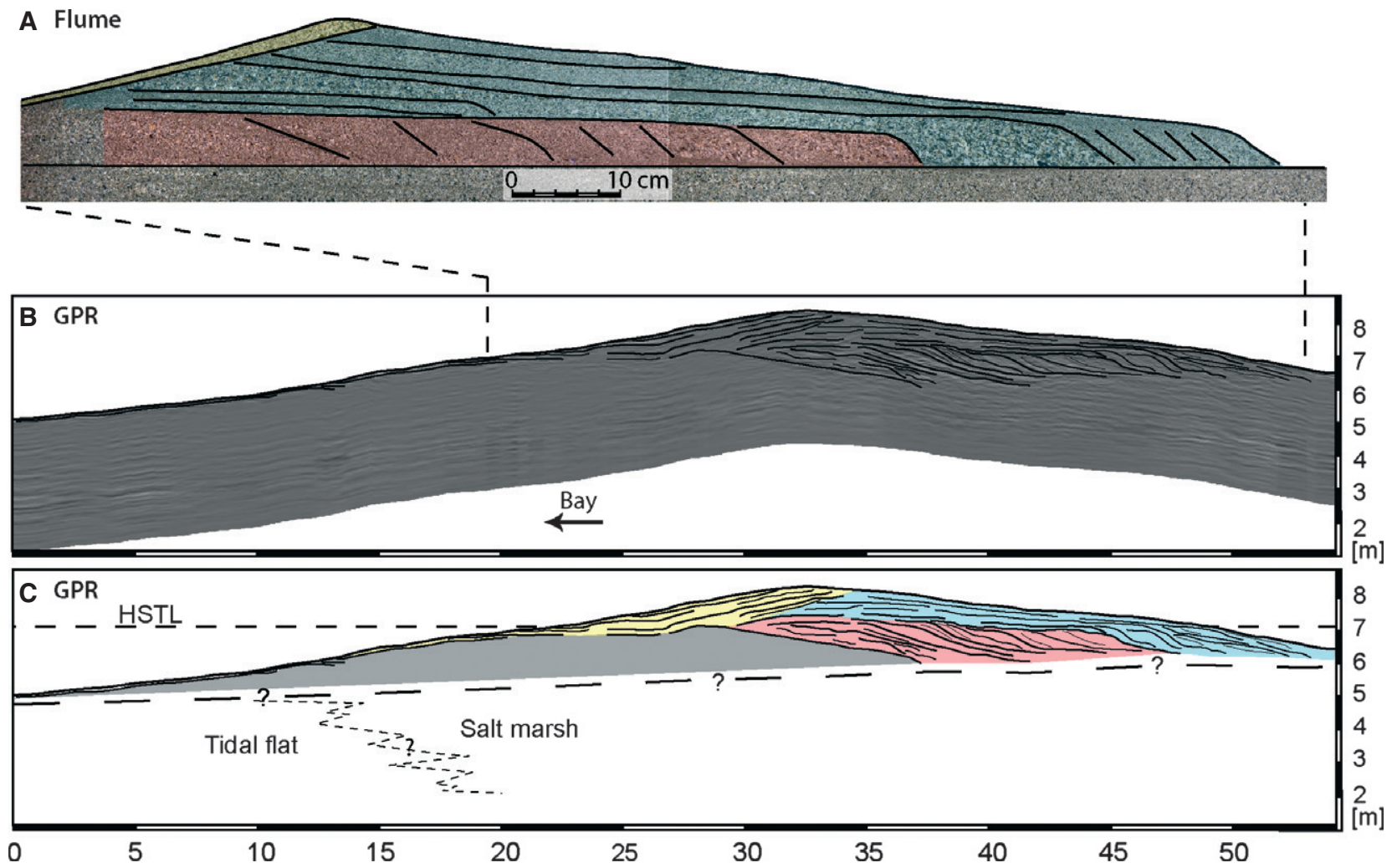

Fig. 11. Comparisons between the modelled beach ridge in the flume at Stage 1 (A) and the GPR profile (B) and interpretation (C) of the late transgressive beach ridge stage ('GPR 2' profile, Fig. 2). The different sedimentary units are defined by colours: Red - Washover foreset unit; Blue - Washover sheet unit; Yellow - Berm unit. Elevation in m above m.s.l. HSTL = high spring tide level.

photograph of the flume illustrates each stage in the evolution of the flume ridge model (Fig. 10).

Despite the fact that the experiment was not reproduced several times with the same initial conditions, the morphological responses of the experimental beach ridge to water level fluctuations were consistent between the two stages of decreasing water level (Stages 2 and 8), as well as between the different stages of rising water level (Stages 4, 6 and 10). This observation was confirmed by an additional cycle of water level falling and rising performed after Stage 11, not presented here. It suggests that the reproducibility of the experiment is good.

\section{DISCUSSION}

\section{Beach ridge morphology comparisons: field data versus flume experiment}

A beach ridge with a complex internal architecture was created in a wave flume. Wave parameters remained constant, water level fluctuations were kept at low frequency. Sediment was obtained from sources in the field. Just as in the field, transport processes in the flume were represented by breaker, swash and overwash transport processes. The experimental beach ridge displayed a narrow, steep bayward slope and a broad, gently inclined landward slope constructed by overwash. Even though the length scales between the field and the flume were distorted, and dynamic similitude was not achieved, the similarity of morphologies and dynamics between the natural and the experimental beach ridge is striking. The closest correlations were between the late transgressive beach ridge stage (Fig. 4B) and Stage 1 of the model (Fig. 10). A similar concordance existed between the progradational beach ridge stage (Fig. 4C) and the experimental ridge at Stage 11 (Fig. 10). Stages 1 and 11 represented the beginning and end stages of the flume experiment. The changes between these two stages define an evolutionary model based on water level fluctuations, landform morphology and internal ridge architecture.

The simulated beach ridge at Stage 1 was $1.30 \mathrm{~m}$ wide and $15 \mathrm{~cm}$ high. The bayward and landward slope angles of the ridge measured $15^{\circ}$ 

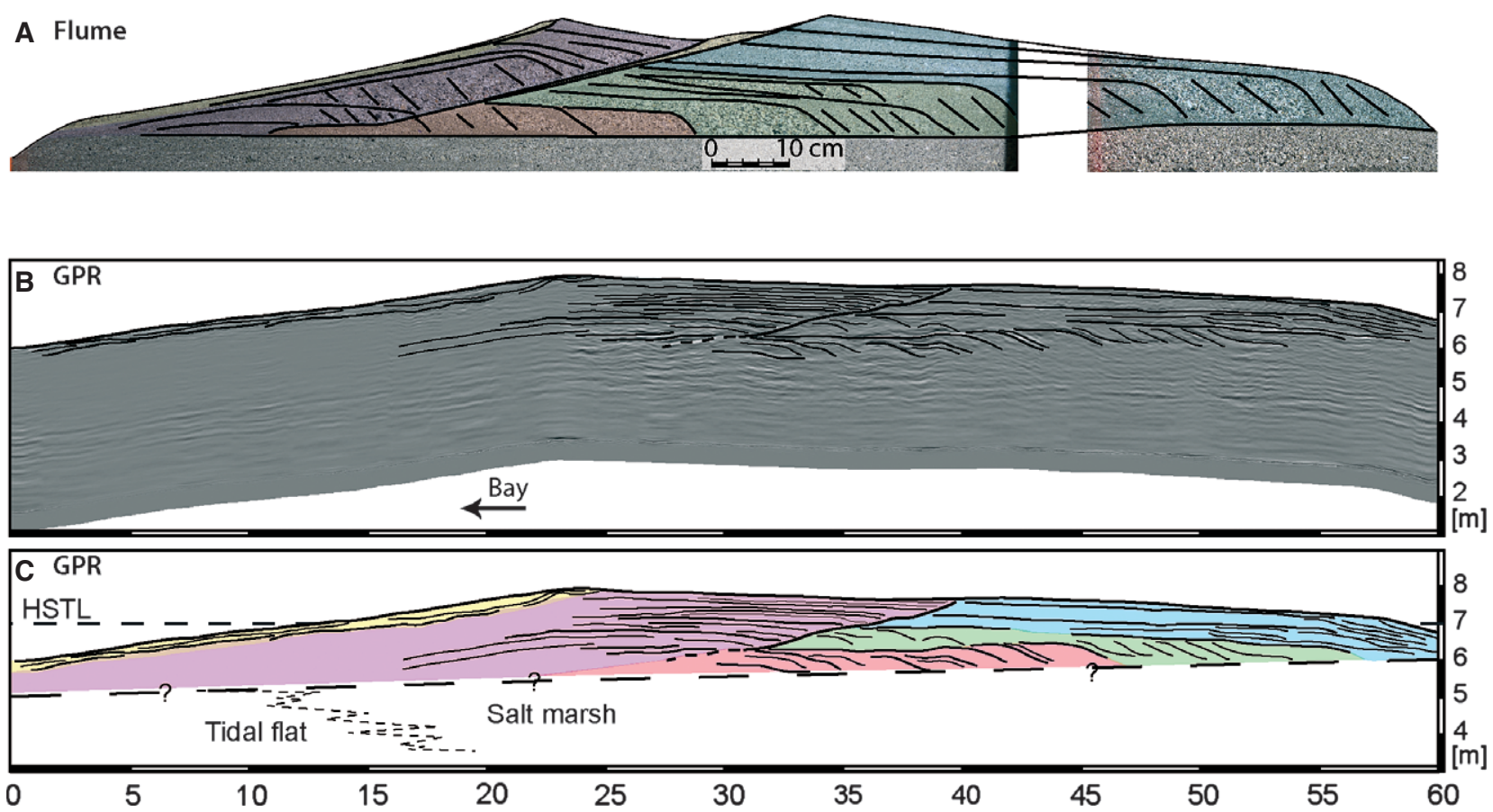

Fig. 12. Comparisons between the modelled beach ridge in the flume at Stage 11 (A) and the GPR profile (B) and interpretation (C) for the prograded beach ridge stage ('GPR 3' profile, Fig. 2). The different sedimentary units are defined by colours: Red - Washover foreset unit; Green - Vertically stacked foreset unit; Blue - Washover sheet unit; Yellow - Berm unit; Purple - Amalgamated ridge unit. Elevation in m above m.s.l. HSTL = high spring tide level.

and $5^{\circ}$, respectively. The experimental ridge was composed of two sizable washover units. The first, tinted in orange (Fig. 11A), was composed of landward-dipping foreset strata, characteristics of subaqueous overwash layers. This unit laid directly on the surface over which the ridge migrated landward. It was deposited below the static water level in the flume, in the depression behind the ridge. Tinted in blue, the second unit (Fig. 11A) covered the washover foresets unit. It was composed of gently landward dipping sub-parallel laminae, typical of washover sheets that were deposited on the sub-aerial part of the ridge backslope, above the static water level in the flume. It was $c a 8 \mathrm{~cm}$ thick. The landward extremities of these aggrading washover sheets were deposited in the flooded depression behind the ridge as high-angle foreset laminae. The two units were truncated on the bayward side of the ridge by the beach erosion surface that revealed the older washover deposits. Observations in the flume revealed that, in the next stages of evolution, these washover deposits exposed on the beach face were eroded by waves and transported by overwash across the landward slope. A new washover unit formed and this contributed to the landward migration of the ridge. Finally, a thin layer of upward increasing grain size covered the beach face. It reached a thickness of $1.5 \mathrm{~cm}$ at the ridge crest. In comparison, the late transgressive beach ridge in the field (Fig. 4B and 'GPR 2' profile in Fig. 2) was $55 \mathrm{~m}$ wide and $2.5 \mathrm{~m}$ high. The bayward and landward slopes were inclined at lesser angles $\left(5^{\circ}\right.$ and $2^{\circ}$, respectively). It was also composed of two washover units, with the same internal structure. The lower washover foreset unit (orange unit, Fig. 11C) was $c a 1.5 \mathrm{~m}$ thick. It was covered by aggrading washover sheets (blue unit, Fig. 11C) $80 \mathrm{~cm}$ thick. The baywardinclined berm deposits (yellow unit, Fig. 11C) of the beach ridge were $70 \mathrm{~cm}$ thick. However, due to the salt and moisture content of the sediment, the GPR method failed in the lower internal part of the ridge (grey unit, Fig. 11C). By analogy, flume observations suggested that spring tide level controls the transition between washover foresets deposited over the tidal flat/salt marsh surface, in the flooded back-barrier depression, and the aggrading washover sheets. The opaque GPR profile interval represents old washover deposits laid down on the tidal flat surface that are exposed on the beach face and eroded as the ridge migrates landward.

In Stage 11, the simulated beach ridge was $1.90 \mathrm{~m}$ wide and $16.5 \mathrm{~cm}$ thick. The bayward 
and landward slope angle of the ridge measured $10^{\circ}$ and $6 \cdot 5^{\circ}$, respectively. The central section of the beach ridge left over from Stage 1 consisted of three washover units (Fig. 12A). The first, tinted in orange, consisted of foreset laminae laid down on the ridge migration surface. Tinted in green, the second unit displayed another small set of foreset strata that overlie the orange unit. This configuration occurred at very high water levels that covered the first washover foreset unit, allowing deposition of subaqueous strata over it, thus mimicking tide conditions in the field. Finally, a large blue-tinted unit consisted of washover sheets deposited above the static water level. This unit underlies the entire landward slope of the beach ridge. The vertical accretion amounted to 9. The purple unit in the flume model consisted of a small intertidal ridge formed at low water level. Low water level allowed waves to rework and accumulate sediment on the flat surface offshore the ridge toe. With a subsequent rise of water level, the new sand ridge thickened by overwash accretion and migrated landward along the main beach ridge foreshore. As the newly formed ridge was raised above the static level of water in the flume, the inclination of the foreset laminae gradually decreased. In comparison, the progradational beach ridge in the field (Fig. 4C and 'GPR 3' profile in Fig. 2) was $c a 60 \mathrm{~m}$ wide and a maximum of $3 \mathrm{~m}$ thick. The bayward and landward slopes were inclined at angles of $5 \cdot 5^{\circ}$ and $3^{\circ}$, respectively. The internal architecture was very similar to that observed in the flume at Stage 11. Two vertically stacked washover foreset units (orange and green units, Fig. 12C) were covered by a $90 \mathrm{~cm}$ thick washover sheet unit (blue unit, Fig. 12C). These three units were truncated by an erosional surface inclined bayward with an angle of $8 \cdot 5^{\circ}$. This surface was onlapped by the strata of a large unit (purple unit, Fig. 12C). By analogy with the flume experiment, this unit was attributed to an intertidal sand ridge that migrated landward and has finally collided with the main beach ridge. The height of that ridge prevented overwash from taking place.

The experimental results suggested that, in the field, the crest elevation of the beach ridge relative to high spring tide (HST) level influenced sediment supply from landward-migrated and reworked intertidal sand ridges. If the crest elevation of the beach ridge was low, intertidal sand ridges were reworked by overwash and contributed to the landward extension of the beach ridge backslope. On the other hand, when the crest elevation was so high as to prevent overwash, the intertidal sand ridges were reworked on the foreshore. This process contributed to beach ridge progradation towards the Bay.

\section{Time scale comparisons}

While the morphological conditions and internal structures created in the flume resemble those in the field, the comparison of time scale and sediment flux are more difficult to determine. Waves generated in the flume are not comparable with breakers along the shore. Similarly, a cycle of rising and falling water level in the flume is not comparable with a cycle of rising and falling tide in terms of the associated volume of transported sediment. Because the experimental model used here did not comply with the criterion of similitude, time-scaling between the flume and field conditions defy quantification.

The flume model provided a continuous simulation of events that, instead, were episodic and discontinuous in the field. Because of their position on the upper tidal flat, at the edge of the salt marsh, only during spring tides were modern beach ridges reworked by waves, representing a cumulative annual total of 160 to $270 \mathrm{~h}$ of tidal inundation (Fig. 3). These values disregard wave heights that were sufficient for the generation of significant sediment transport. In the flume model, the simulated beach ridge was continuously affected by wave action. The main impact of water level fluctuations was the change in the width of the beach foreshore over which waves operated and occasionally generated overwash over the landward ridge slope.

In terms of the hydrodynamic and sedimentary processes, the contrasting time scales in the field overlapped with those in the flume runs. The processes of sediment sorting in the breaker zone, and sediment transport and deposition in the swash zone, as well as in the overwash, are comparable between flume conditions and in the field. There was little time-scale distortion between flume and field processes. The sediment used in the flume was identical to that in the field. As a consequence, the upward-coarsening trend caused by rising water-level in the simulated flume foreshore sequence was also encountered and scalable in the field during the last hours of the rising tide. This also allowed 
comparisons of conditions between falling water level in the flume and the start of falling tide in the field. At this stage, the foreshore surface was covered by falling water marks, etched by transported coarse bioclasts. The same sorting process occurred on the backslope of beach ridges during overwash. Coarse bioclasts were transported greater distances towards the back-barrier zone, resulting in a coarsening grain size on the ridge backslope from the beach ridge crest to the toes of the overwash fans. The aggrading washover sand sheets consisted of finer size fractions. An identical grain sorting was observed horizontally along the backslope, and vertically between the base of the washover lobes and the aggrading washover sheets.

Simulated beach erosion in the flume by the breaking waves and the subsequent sediment overwash across the backslope resulted in the landward migration of the beach ridge towards the back-barrier depression. Thus, during Stages 6 and 7 (Fig. 10), the crest of the ridge moved as much as $1 \mathrm{~m}$ in $2.5 \mathrm{~h}$. The total width of the beach ridge was $c a 1.5 \mathrm{~m}$. As a result, during intense sediment reworking associated with high water level in the flume, almost the entire sediment volume of the beach ridge was removed from the foreshore and reworked into overwash deposits. Aerial photographs indicate that beach ridges in the field moved at a rate of $c a 50 \mathrm{~m}$ in three to six years. This distance equals the ridge width. The landward migration observed in the flume within $2 \mathrm{~h}$ is comparable with distances of multi-annual ridge movement in the field. Prolonged duration of tidal flooding during HST allows the overwash to top the ridge crest. This process takes place annually in the space of a cumulative total of $50 \mathrm{~h}$. Ridge migration requires 150 to $300 \mathrm{~h}$ of high-tidal inundation for a three to six-year period to allow ridge migration over a distance that equals the width of individual beach ridges.

How do flume cycles of raised and lowered water level simulate actual field conditions? In considering the landforms created and the important volume of sediment that is being reworked, water level fluctuations should not be compared with semi-diurnal rise and fall of tides. Flume simulation, however, may reflect the effects of lower frequency cycles over longer time intervals. Because the waves impact beach ridges only during HSTs, the water level fluctuations in the flume do continuously simulate variations in elevations attained by HSTs in the field. Water level fluctuations in the flume may correspond to variations in the flooding frequency of the beach ridges. The cycles utilized in the experimental runs thus correspond to low-frequency, 4.4 year and 18.6 year tidal cycles (Fig. 3). Low-frequency tidal cycles have been investigated in other studies: Gratiot et al. (2008) showed that an 18.6 year tidal cycle may influence accretion and erosion of mud banks along the Guyana chenier coast.

\section{Role of low-frequency tidal level fluctuations}

Since water level was the only variable parameter in the flume, and experiments reproduced most of the complexity involved in the natural system, sea-level fluctuation represents the main controlling factor in the evolution and internal structure of beach ridges in the investigated macrotidal chenier plain. High spring tides do re-activate modern beach ridges on the upper tidal flat by erosion of foreshore sediments and their deposition in washover fans on the ridge backslope. Tide levels control the morphology and internal structure of the investigated beach ridges in two ways. First, tide controls the vertical transition within washover fans between foreset strata formed by sub-aqueous deposition in the flooded back-barrier depression, and sand sheets laid down by overwash over the wet subaerial beach ridge backslope. Secondly, the level of tidal flooding with respect to the beach ridge elevation is a driving factor behind the evolution of these coastal sedimentary bodies. In the early transgressive stage (Fig. 4A), the ridges are frequently flooded and experience both landwardmigration and landward-extension by washover deposition. In the late transgressive stage (Fig. 4B), the ridges are thicker and less frequently submerged. Landward-extension of the backslope ceases as most of the overwashed sand settles on the ridge backslope before reaching the back-barrier depression. The ridges are stabilized as washover deposition subaerially aggrades the back-slope. During progradation (Fig. 4C), the recently elevated ridges resist overwash. Sediment deposition is confined to the foreshore; this results in bayward ridge extension, occasionally by the amalgamation of small intertidal sand ridges.

Fluctuations in tide levels and the duration of flooding during spring tides underlie the overall dynamics of the beach ridge system. Based on the combination of field data and experimental results, a depositional model is proposed. During lower HSTs, or lower frequency of tidal 
flooding, the beach ridges are stable and rarely affected by overwash. Coarse-grained sediment reworked from the tidal flat accumulates in small intertidal sand ridges that form on the tidal flat, several tens of metres offshore from the beach ridges. When HSTs are more frequent, the intertidal sand ridges are reworked and undergo landward migration, thus contributing to the growth of beach ridges that form along the edge of the salt marsh. Depending on the degree of development and elevation of the beach ridges, the sediment that the ridges receive may be reworked by washover processes that force the ridge backslope to extend landward and during this transgressive stage to cover the salt marsh. Sediment may also accumulate on the ridge foreshore when high enough to prevent overwash; this results in bayward progradation of the beach ridge. Alternating periods of lower and higher frequency of spring tide flooding (Fig. 3) trigger periods of beach ridge stabilization, respectively of beach ridges reworking. During reworking, ridges may be extended both landward and bayward.

\section{CONCLUSION}

Flume modelling has been a key element in the study of low-frequency tidal level fluctuations on beach ridge architecture in a megatidal chenier plain setting. In order to isolate the action of forcing parameters observed in the field, and to simulate continuously high water levels associated with spring tides, a wave flume experiment was designed. Natural bioclastic sediment sampled in the field was exposed to constant wave forcing and variable water level in an $18 \mathrm{~m}$ long wave flume. Although rigorous scaling was not achieved, sedimentary processes were very similar to those observed in the field. The initial smooth beach rapidly evolved into a beach ridge with a steep bayward slope, and a low angle landward slope formed by overwash processes. Washover deposits displayed two distinct patterns. Washover sheets were deposited above static water level, while foreset layers formed subaqueously. Water level fluctuations and constant wave forcing in the flume triggered a rapid morphological response in the ridge. The internal architecture of the beach ridge at different stages of its evolution matched groundpenetrating radar data from the field.

The fact that most internal structure found in natural beach ridges was reproduced in the flume runs by constant wave forcing and variations of mean water level strongly suggests that low-frequency tidal level fluctuation is the main parameter that controls the dynamics and evolution of beach ridges, including their internal architecture. In the field, low-frequency water level fluctuations are related to the 4.4 year and $18 \cdot 6$ year tidal cycles. It therefore seems likely that these cycles represent the underlying factor in the evolution of the macrotidal chenier coast at the multi-decadal to centennial time scale. Other forcing factors, not considered in this study, may episodically modify the evolution and internal structure of the beach ridges. These factors include erosive storm waves, variation in the sediment supply and the biological productivity in the coastal area.

Beyond the particular environment of chenier plains, this study emphasizes the importance of low-frequency sea-level fluctuations during the development of tide-impacted coastal sedimentary lithosomes.

\section{ACKNOWLEDGEMENTS}

This paper is based on the doctoral dissertation by P. Weill (UMR M2C, University of Caen Basse-Normandie), funded by the Regional Council of Basse-Normandie (France). The authors wish to thank the Chief Editor, Stephen Rice, and the reviewers (Antonio RodriguezRamirez, Joep Storms and Ervin Otvos), for their insightful reviews and comments. We are especially indebted to Ervin Otvos for his time and assistance in correcting and improving the manuscript. We are thankful to Sylvain Haquin and Laurent Perez, who provided great technical support for the flume experiment, and to JeanClaude Brun-Cottan for the fruitful discussions throughout this work. The GPR survey would not have been possible without the assistance of Christophe Norgeot (MDS Paris).

\section{REFERENCES}

Anthony, E.J. (1989) Chenier plain development in northern Sierra Leone, West Africa. Mar. Geol., 90, 297-309.

Augustinus, P. (1980) Actual development of the chenier coast of Suriname (South America). Sed. Geol., 26, 91-113.

Augustinus, P.G.E.F. (1989) Cheniers and chenier plains: a general introduction. Mar. Geol., 90, 219-229.

Augustinus, P.G.E.F., Hazelhoff, L. and Kroon, A. (1989) The chenier coast of Suriname: modern and geological development. Mar. Geol., 90, 269-281. 
Bagnold, R. (1956) The flow of cohesionless grains in fluids. Proc. Roy. Soc. London, 249, 235-297.

Bonnot-Courtois, C., Fournier, J. and Dréau, A. (2004) Recent morphodynamics of shell banks in the western part of MontSaint-Michel Bay (France). Géomorphologie., 1, 65-80.

Byrne, J.V., Leroy, D.O.S. and Riley, C.M. (1959) The chenier plain and its stratigraphy, southwestern Louisiana. Trans. Gulf Coast Assoc. Geol. Soc., 9, 237-260.

Cangzi, L. and Walker, H. (1989) Sedimentary characteristics of cheniers and the formation of the chenier plains of East China. J. Coastal Res., 5, 353-368.

Chappell, J. and Grindrod, J. (1984) Chenier plain formation in Northern Australia. In: Coastal Geomorphology in Australia (Ed. B.G. Thom), pp. 197-231. Academic Press, Australia.

Dette, R., Larson, M., Murphy, J., Newe, J., Peter, K., Reniers, A. and Steetzel, H. (2002) Application of prototype flume tests for beach nourishment assessment. Coast. Eng., 47, 137-177.

Draut, A.E., Kineke, G.C., Velasco, D.W., Allison, M.A. and Prime, R.J. (2005) Influence of the Atchafalaya River on recent evolution of the chenier-plain inner continental shelf, northern Gulf of Mexico. Cont. Shelf Res., 25, 91-112.

Grasso, F., Michallet, H., Barthélemy, E. and Certain, R. (2009a) Physical modelling of intermediate cross-shore beach morphology: transients and equilibrium states. J. Geophys. Res., 114, 1-15.

Grasso, F., Michallet, H., Certain, R. and Barthélemy, E. (2009b) Experimental flume simulation of sandbar dynamics. J. Coastal Res., 56, 54-58.

Gratiot, N., Anthony, E., Gardel, A., Gaucherel, C., Proisy, C. and Wells, J. (2008) Significant contribution of the 18.6 year tidal cycle to regional coastal changes. Nat. Geosci., 1, 169-172.

Greensmith, J.T. and Tucker, E.V. (1969) The origin of Holocene shell deposits in the chenier plain facies of Essex (Great Britain). Mar. Geol., 7, 403-425.

Hayward, B. (2007) Protecting New Zealand's earth science heritage - chalazoidites and cheniers. Geol. Soc. New Zealand (GSNZ) Newsletter, 142, 22-27.

Hickson, T., Sheets, B., Paola, C. and Kelberer, M. (2005) Experimental test of tectonic controls on three dimensional alluvial facies architecture. J. Sed. Geol., 75, $710-722$

Holland, K. and Elmore, P. (2008) A review of heterogeneous sediments in coastal environments. Earth-Sci. Rev., 89, 116-134.

Hoyt, J. (1969) Chenier versus barrier, genetic and stratigraphic distinction. AAPG Bull., 53, 299-306.

Larsonneur, C. (1994) The Bay of Mont-Saint-Michel: a sedimentation model in temperate macrotidal environment. S. Maritima, 24, 3-63.

Lee, H.J., Chun, S.S., Chang, J.H. and Han, S.-J. (1994) Landward migration of isolated shelly sand ridge (chenier) on the macrotidal flat of Gosmo Bay, West coast of Korea: controls of storms and typhoon. J. Sed. Res., A64, 886893.

L'Homer, A., Bonnot-Courtois, C. and Caline, B. (2002) The depositional wedge of the Dol marsh: an attempt at reconstitution of the deposition. In: The Bay of MontSaint-Michel and the Rance Estuary - Recent Development and Evolution of Depositional Environments (Eds C. Bonnot-Courtois, A. L'Homer and M. Le Vot), Mém. Elf-Aquitaine, 26, 177-196.
Lopez de San Roman-Blanco, B., Coates, T., Holmes, P., Chadwick, A., Bradbury, A., Baldock, T., Pedrozo-Acuæa, A., Lawrence, J. and Grüne, J. (2006) Large scale experiments on gravel and mixed beaches: experimental procedure, data documentation and initial results. Coast. Eng., 53, 349-362.

Martin, J., Paola, C., Abreu, V., Neal, J. and Sheets, B. (2009) Sequence stratigraphy of experimental strata under known conditions of differential subsidence and variable base level. AAPG Bull., 93-4, 503-533.

McBride, R.A., Taylor, M.J. and Byrnes, M.R. (2007) Coastal morphodynamics and Chenier-Plain evolution in southwestern Louisiana, USA: a geomorphic model. Geomorphology, 88, 367-422.

Michallet, H., Grasso, F. and Barthélemy, E. (2007) Long waves and beach profiles evolutions. J. Coastal Res., 50, 221-225

Morzadec-Kerfourn, M.-T. and Meury, J. (1995) Geomorphological significance of the Great Groove in the Dol marsh. Dossiers du Centre Régional d'Archéologie d'Alet, Suppl. ${ }^{\circ} \mathbf{R}, 59-65$.

Muto, T. (2001) Shoreline autoretreat substantiated in flume experiments. J. Sed. Res., 71-2, 246-254.

Muto, T. and Steel, R. (2001) Autostepping during the transgressive growth of deltas: results from flume experiments. Geology, 29, 771-774.

Muto, T. and Steel, R. (2004) Autogenic response of fluvial deltas to steady sea-level fall: implications from flume experiments. Geology, 32, 401-404.

Neal, A., Richard, J. and Pye, K. (2002) Structure and development of cheniers in Essex, southeast England, investigated using high-frequency ground-penetrating radar. Mar. Geol., 185, 435-469.

Otvos, E. (2005) Cheniers: definition and morphology. In: Encyclopedia of Coastal Science (Ed. E.G. Schwartz), pp. 233-235. Springer Verlag, Berlin.

Otvos, E.G. and Price, W.A. (1979) Problems of chenier genesis and terminology - an overview. Mar. Geol., 31, 51-63.

Paola, C. (2000) Quantitative models of sedimentary basin filling. Sedimentology, 47, 121-178.

Paola, C., Straub, K., Mohrig, D. and Reinhardt, L. (2009) The "unreasonable effectiveness" of stratigraphic and geomorphic experiments. Earth-Sci. Rev., 97, 1-43.

Penland, S. and Suter, J.R. (1989) The geomorphology of the Mississippi River chenier plain. Mar. Geol., 90, 231-258.

Pontee, N., Tastet, J. and Masse, L. (1998) Morphosedimentary evidence of Holocene coastal changes near the mouth of the Gironde and on the Medoc Peninsula, SW France. Oceanol. Acta, 21, 243-261.

Qinshang, Y., Shiyuan, X. and Xusheng, S. (1989) Holocene cheniers in the Yangtze delta. China. Mar. Geol., 90, 337343.

Rhodes, E. (1982) Depositional model for a chenier plain, Gulf of Carpentaria, Australia. Sedimentology, 29, 201-221.

Rodríguez-Ramírez, A. and Yáñez-Camacho, C.M. (2008) Formation of chenier plain of the Donaña marshland (SW Spain): observations and geomorphic model. Mar. Geol., 254, 187-196.

Ruiz, F., Rodríguez-Ramírez, A., Cáceres, L.M., Vidal, J.R., Carretero, M.I., Abad, M., Olías, M. and Pozo, M. (2005) Evidence of high-energy events in the geological record: mid-Holocene evolution of the southwestern Donaña National Park (SW Spain). Palaeogeogr. Palaeoclimatol. Palaeoecol., 229, 212-229. 
Saito, Y., Wei, H., Zhou, Y., Nishimura, A., Sato, Y. and Yokota, S. (2000) Delta progradation and chenier formation in the Huanghe (Yellow River) delta. China. J. Asian Earth Sci., 18, 489-497.

Schwartz, R. (1982) Bedform and stratification characteristics of some modern small-scale washover sand bodies. Sedimentology, 29, 835-849.

Shields, A. (1936) Application of similarity principles and turbulence research to bed-load movement. Mitteilunger der Preussischen Versuchsanstalt für Wasserbau und Schiffbau, 26, 5-24.

Short, A. (1988) The South Australian coast and Holocene sea-level transgression. Geogr. Rev., 78, 119-136.

Short, A. (1989) Chenier research on the Australian coast. Mar. Geol., 90, 345-351.

Shuisky, Y. (1989) Approaches to the study of cheniers along the coastline of the Soviet Union. Mar. Geol., 90, 289-296.

Tessier, B., Billeaud, I. and Lesueur, P. (2006) The Bay of Mont-Saint-Michel northeastern littoral: an illustrative case of coastal sedimentary body evolution and stratigraphic organization in a transgressive/highstand context. Bull. Soc. Géol. Fr., 177, 71-78.

van Thiel, J., van Gent, M., Walstra, D. and Reniers, A. (2008) Analysis of dune erosion processes in large-scale flume experiments. Coast. Eng., 55, 1028-1040.

Vilas, F., Arche, A., Ferrero, M. and Isla, F. (1999) Subantartic macrotidal flats, cheniers and beaches in San
Sebastian bay, Tierra Del Fuego. Argentina. Mar. Geol., 160, 301-326.

Wang, T. and Kraus, N. (2005) Beach profile equilibrium and patterns of wave decay and energy dissipation across the surf zone elucidated in a large-scale laboratory experiment. J. Coastal Res., 21, 522-534.

Wang, H. and Van Strydonck, M. (1997) Chronology of Holocene cheniers and oyster reefs on the coast of Bohai Bay. China. Quat. Res., 47, 192-205.

Weill, P., Mouazé, D., Tessier, B. and Brun-Cottan, J.C. (2010) Hydrodynamic behaviour of coarse bioclastic sand from shelly cheniers. Earth Surf. Proc. Land., 35, 16421654.

Weill, P., Tessier, B., Mouazé, D., Bonnot-Courtois, C. and Norgeot, C. (2012) Shelly cheniers on a macrotidal flat (MontSaint-Michel bay, France) - internal architecture revealed by ground-penetrating radar. Sed. Geol., 279, 173-186.

Woodroffe, C.D., Curtis, R.J. and McLean, R.F. (1983) Development of a chenier plain, firth of Thames, New Zealand. Mar. Geol., 53, 1-22.

Xitao, Z. (1989) Cheniers in China: an overview. Mar. Geol., 90, 311-320.

Manuscript received 24 November 2011; revision 31 August 2012; 